\title{
PHYSICOCHEMICAL PARAMETERS AND HEAVY METALS CONTENT OF SOIL SAMPLES FROM FARMS IN MINNA
}

\author{
Z. Abdulhamid ${ }^{1^{\star}}$ E.B. Agbaji ${ }^{2}$, C.E. Gimba ${ }^{2}$ and A. S. Agbaji ${ }^{3}$ \\ ${ }^{1}$ School of Science C.O.E. Minna, Nigeria \\ ${ }^{2}$ Department of chemistry A.B.U. Zaria, Nigeria \\ ${ }^{3}$ Department of biochemistry, Kaduna State University, Nigeria \\ E-mail address: zulaihatabdulhamid@gmail.com
}

Keywords: Parameters; Physico-chemical; Heavy metals; Soil

\begin{abstract}
Physico-chemical properties and heavy metals content of soils were determined from seven farms in Minna, central Nigeria. Conventional analytical methods were employed to determine the physico-chemical properties and the heavy metals were analysed by atomic absorption spectrometry. The result showed that $\mathrm{pH}$ values ranged from $6.64-7.70$ indicating slight acidity to slight alkalinity of the soils. The total organic carbon values ranged from $0.95-2.25 \%$ resulting in the presence of organic matter (1.63-3.87). The electrical conductivity values ranged from 17-37 $\mu \mathrm{S} / \mathrm{cm}$. The cation exchange capacity of the soil samples ranged from 3.68-5.15 $\mathrm{cmol} / \mathrm{kg}$. The heavy metals levels were in the following range: $\mathrm{Cd}(0.00018-0.00134 \mathrm{mg} / \mathrm{g}), \mathrm{Cu}$ $(0.0069-0.0476 \mathrm{mg} / \mathrm{g}), \mathrm{Fe}(1.942-2.2059 \mathrm{mg} / \mathrm{g}), \mathrm{Mn}(0.1825-0.3696 \mathrm{mg} / \mathrm{g}), \mathrm{Ni}(0.0065-0.0069$ $\mathrm{mg} / \mathrm{g})$ and $\mathrm{Zn}(0.0157-0.2252 \mathrm{mg} / \mathrm{g})$. The concentration of the metals in the soil samples varied according to the following trend: $\mathrm{Fe}>\mathrm{Mn}>\mathrm{Zn}>\mathrm{Cu}>\mathrm{Ni}>\mathrm{Cd}$. The average concentration of all the metals in each farm also gave the trend Farm $B>$ Farm $G>$ Farm $E>$ Farm $C>$ Farm $F>$ Farm $D>$ Farm A. The findings indicate the presence of heavy metals in all the farms but only Fe was above the FAO/WHO standards.
\end{abstract}

\section{INTRODUCTION}

Heavy metals like iron tin copper, manganese and vanadium occur naturally in the environment and could serve as plant nutrients depending on their concentrations. Mercury, lead, cadmium, silver, chromium and many others that are indirectly distributed as a result of human activities could be very toxic even at low concentrations (Opaluwa et al., 2012). Those most commonly found at contaminated sites are lead, chromium, arsenic, zinc, cadmium, copper, mercury, and nickel (GWRTAC, 1997).

Heavy metals are extremely persistent in the environment because of their non-biodegradable nature, thermal stability and potential to accumulate to toxic levels, even at low concentrations. These metals can pose a significant health risk producing damaging effects on man and animals because there is no good mechanism for their elimination from the body (Arora et al., 2008; Yusuf et al., 2009).

There is a growing concern about the possibility of agricultural soil's contamination by heavy metals resulting in uptake by plants and their introduction in vital food chains affecting food safety (Pujar et al., 2012). The contamination is often a direct or indirect consequence of anthropogenic activities from urban and industrial wastes, mining and smelting of non-ferrous metals and metallurgical industries (McLaughlin et al., 1999, Singh, 2001). Other ways of metal accumulation in soil is by irrigating farmland with poor quality water, weathering of rocks, transportation and disposal of high metal waste on farmland and leaching from refuse dumpsite (Dosumu, et al., 2005).

Soils may also become contaminated by the accumulation of heavy metals and metalloids from leaded gasoline and paints, land application of fertilizers, animal manures, sewage sludge, pesticides, coal combustion residues, and spillage of petrochemicals (Khan et al., 2008 and Zhang 
et al., 2010). Knowledge of the total metal concentration provides limited information about their potential mobility and bioavailability (Bashir et el., 2014). The movement and availability of the important micronutrients such as $\mathrm{Mn}, \mathrm{Fe}, \mathrm{Zn}$ and $\mathrm{Cu}$ change due to soil conditions which are controlled by plant species and a number of soil parameters like the nature of complexes in which the metal is present in soil, $\mathrm{pH}$, cation exchange capacity, amount of organic matter and particle size (Adriano, 1986).

Top soil and road side soil near heavy traffic in urban areas are indicators of heavy metal contamination from atmospheric deposition. Metals such as $\mathrm{Cd}, \mathrm{Cu}, \mathrm{Pd}$ and $\mathrm{Zn}$ are good indicators of contamination in soils because they appear in gasoline, car component, oil lubricants and industrial incinerator emissions (Popoola et al., 2012, Olukanmi and Adeoye 2012).

This study examined the physicochemical properties and the levels of $\mathrm{Cd}, \mathrm{Cu}, \mathrm{Fe}, \mathrm{Mn} \mathrm{Ni}$ and $\mathrm{Zn}$ in soils from farms around Minna, central Nigeria resulting from possible anthropogenic activities. Minna lies on latitude $9^{0} 37^{\prime}$ North and longitude $6^{0} 33^{\prime}$ East and at an elevation of $356 \mathrm{~m}$ $(841 \mathrm{Ft})$. The selected farms for this research are situated by the road sides, near dumpsites, mechanic workshops, car parks and thus have an elevated risk of potential contamination.

\section{MATERIALS AND METHOD}

\subsection{Sampling Sites}

The samples that were used for the research were taken from seven selected farms in the following areas of Minna: (A) Okada Road, (B) Kpakungu, (C) Dutsen kura, (D) Keteren gwari (E) Chanchaga (F) Mandela (G) Sauka ka huta.

\subsection{Samples Collection and Preparation}

Soil samples were collected from a depth of 10 to $15 \mathrm{~cm}$, from the surface as described by Allen (1974). From each farmland, ten soil samples were collected from ten different spots, which were pooled together to form a composite of each individual sample. They were placed in clean dried polythene bags, labelled and transported to the laboratory for analysis. The soil samples were air dried, disaggregated with porcelain pestle and mortar and finely powdered to pass through $2 \mathrm{~mm}$ mesh sieve for homogeneity. Soil samples were analysed for the following parameters: $\mathrm{pH}$, electrical conductivity, particle size, organic matter, organic carbon, cation exchange capacity and heavy metals.

\subsection{Determination of Physico-chemical Parameters}

All the chemicals and reagents used were of analytical standard. The determination of particle sizes of the soil samples was carried out using Bouyoucos Hydrometer method. The $\mathrm{pH}$ of the soil samples was determined using $\mathrm{pH}$ meter in 1:1 soil water suspension, electrical conductivity was determined in the filtrate of the water extract using Conductivity meter. The Percentage Organic carbon/matter was determined by using chromic acid wet oxidation method by Walkey and Black (1934). Ca and $\mathrm{Mg}$ were determined by complexometric titration with EDTA, Na and K by flame photometry, exchangeable acidity by acid-base titration while cation exchange capacity was obtained by summing up the exchangeable bases.

\subsection{Determination of Heavy metals}

The digestion procedure used for determining heavy metals was as recommended by AOAC, described by Omojola, (1993). $1 \mathrm{~g}$ of the dried pulverized samples was weighed each and poured into a $100 \mathrm{ml}$ beaker. $10 \mathrm{~cm}^{3}$ of concentrated nitric acid was added to sample and heated at $40{ }^{0} \mathrm{C}$. After the evolution of brown fumes, heating was continued until a clear solution was obtained. Deionized water was added at intervals to prevent drying of the digest. The clear solution was diluted to $40 \mathrm{~cm} 3$ and filtered with a whatman filter paper No. 41 into a $100 \mathrm{~cm}^{3}$ volumetric flask. The beakers were rinsed thoroughly and then the solution was made up to the mark with de-ionized 
water. It was poured into a $100 \mathrm{~cm}^{3}$ polypropylene bottles and stored in the refrigerator at $4{ }^{0} \mathrm{C}$ for analysis. $1000 \mathrm{ppm}$ stock solutions were prepared from the salts of the metals under investigation and deionized water. Standard solutions were also prepared by serial dilution of the $1000 \mathrm{ppm}$ stock solution of each metal. All metals were determined with a Thermo Scientific ICE 3000 series atomic absorption spectrophotometer. Each sample solution was run in triplicate and the result was corrected by subtracting the blank reading from the value for each metal.

\section{RESULTS AND DISCUSSION}

\subsection{Soil pH and Electrical Conductivity}

The $\mathrm{pH}$ of a soil has a major effect on metal dynamics because it controls adsorption and precipitation, which are the main mechanisms of metal retention in soils. As $\mathrm{pH}$ decreases, the solubility of cationic forms of metal in the soil solution increases and therefore become more readily available to plants. Table 1 gives the result for $\mathrm{pH}, \mathrm{EC}, \mathrm{OM}$ and $\mathrm{OC}$ for all the soil samples The $\mathrm{pH}$ value for normal soil is $5.5-7.5, \mathrm{pH}$ of soil below this range can cause low availability of some essential minerals needed by the soil (Brady and Weil, 2000). The $\mathrm{pH}$ values of all the soil samples analysed from the seven farms ranged from 5.77 to 7.70 showing slightly acidic to slightly basic. This also shows the soil samples are within the range for normal soil $\mathrm{pH}$. Such $\mathrm{pH}$ values are characteristic of soils in areas were leaching is less pronounced due to low precipitation, resulting in the concentration of base forming cations in the place of acid contributing cations such as $\mathrm{Al}^{3+}$ and $\mathrm{H}^{+}$(Ajai et al., 2014). These values are in the same range of (5.0-7.5) reported by Iyaka and Kakulu (2009) and 6.20-6.70 reported by (Sumaila, 2014) for soils from the same area. The pH values are also lower than values $7.2-8.3$ for soil samples in India (Kiran, 2013). Farm E with a lowest pH value of 5.77 may have greater solubility for metals, therefore becoming more readily available for plants.

Conductivity measurements shows farm $\mathrm{G}$ with the lowest value of $17 \mu \mathrm{S} / \mathrm{cm}$ and farm $\mathrm{C}$ has the highest value of $37 \mu \mathrm{S} / \mathrm{cm}$. These values indicate the relative water-soluble salt content of the soil. Electrical conductivity depends on the amount of dissolved minerals and gives the ability of a substance to conduct an electric current at a specific temperature $\left(25^{\circ} \mathrm{C}\right)$. There is no regular pattern of variation in conductivity between sandy, loamy sand or silt loam soil samples. Boulding (1994) classified EC of soils as: non saline $<2$; moderately saline 2-8; very saline 8-16; extremely saline $>16$. Based on this classification, the EC results for this study may be classified as extremely saline.

\subsection{Soil Organic Matter (SOM)}

Soil organic matter has influence on soil structure, water holding capacity, nutrient contributions, biological activity, water and air infiltration rate and pesticide activity. A soil with high level organic matter is an indication of high cation exchange capacity, holds more water and increases biological activities (Horwath, 2005)

The presence of SOM is regarded as being critical for soil function and soil quality, it increases soil fertility by providing cation exchange sites and acting as reserve of plant nutrients like $\mathrm{N}$, $\mathrm{P}$, and $\mathrm{S}$, along with micronutrients, SOM also acts as the major sink and source of soil carbon. Although the Carbon content of SOM is known to vary considerably (Perie and Ouimet, 2008, Jain et al, 1997). The concentration of SOM in soils generally ranges from $1 \%$ to $6 \%$ of the total topsoil mass for most upland soils. Soils whose upper horizons consist of less than $1 \%$ organic matter are mostly limited to desert areas, while the SOM content of soils in low-lying, wet areas can be as high as 90 $\%$. Soils containing 12-18\% soil organic carbon are generally classified as organic soils (Troeh and Louis, 2005). The SOM for the soil samples analysed was 1.63-3.87 \%, which is within the range for upland soils. The organic carbon (OC) is in the range of $0.95-2.25 \%$ which is lower than 12-18 $\%$ for organic soils. 
Table $1 \mathrm{pH}$, conductivity, organic matter and organic carbon of soil samples

\begin{tabular}{|ccccc|}
\hline Farm & $\mathbf{p H}$ & $\begin{array}{c}\text { Conductivity } \\
(\boldsymbol{\mu S} / \mathbf{c m})\end{array}$ & $\begin{array}{c}\text { Organic } \\
\text { matter } \\
(\%)\end{array}$ & $\begin{array}{c}\text { Organic } \\
\text { Carbon } \\
(\%)\end{array}$ \\
\hline A & 7.59 & 24 & 2.44 & 1.42 \\
B & 6.64 & 29 & 3.87 & 2.25 \\
C & 7.25 & 37 & 2.95 & 1.72 \\
D & 7.70 & 20 & 2.06 & 1.20 \\
E & 5.77 & 18 & 3.09 & 1.80 \\
F & 6.73 & 21 & 1.92 & 1.12 \\
G & 7.35 & 17 & 1.63 & 0.95 \\
\hline
\end{tabular}

\subsection{Soil Particle Size}

The results for particle size and texture of the soil samples is as shown in table 2. The textural class of the soil samples were sandy to loamy sandy, with the exception of farm E which was silty loam. The particle size distribution of the soil showed that the soil contained higher composition of sand than silt and clay in all the sampling sites. Trace metals have preferential accumulation in the clay and silt fraction of soil. Generally, the concentration of heavy metal in soil increase with decrease in the sizes of the soil particles (Ajai, et al., 2014).

Table 2 Particle Size $(\mathrm{g} / \mathrm{kg})$ and Texture of Soil Samples

\begin{tabular}{|lclll|}
\hline Farm & Soil & Silt & Clay & Texture \\
\hline A & 95.80 & 1.60 & 4.65 & Sand \\
B & 85.60 & 12.80 & 1.60 & Loamy Sand \\
C & 95.20 & 2.80 & 2.00 & Sand \\
D & 93.20 & 5.00 & 1.80 & Sand \\
E & 65.00 & 33.60 & 1.40 & Silty Loam \\
F & 87.00 & 7.00 & 6.00 & Loamy Sand \\
G & 89.60 & 9.80 & 0.60 & Loamy Sand \\
\hline
\end{tabular}

\subsection{Cation Exchange Capacity (CEC)}

Table 3 shows the result for the effective cation exchange capacity obtained by summing up the values of the exchangeable bases and exchangeable acidity. Cation exchange capacity (CEC) is a measure of the soil's ability to hold positively charged ions. It is a very important soil property influencing soil structure stability, nutrient availability, soil $\mathrm{pH}$ and the soil's reaction to fertilisers (Hazleton and Murphy 2007).

The CEC of soils varies according to the percentage of clay in the soil, the type of clay, soil $\mathrm{pH}$ and amount of organic matter. Organic matter has a very high CEC ranging from 250 to 400 meq/100 g (Moore 1998). Soils with a low CEC are more likely to develop deficiencies in potassium, magnesium and other cations while high CEC soils are less susceptible to leaching of these cations (CUCE 2007). The result from table 3 shows that farm D has the highest CEC value of $5.15 \mathrm{cmol} / \mathrm{kg}$ while farm $\mathrm{G}$ has the least value of $3.68 \mathrm{cmol} / \mathrm{kg}$. A higher CEC usually indicates more clay and organic matter is present in the soil resulting in greater water holding capacity. The soil of farm D with the highest value of CEC will be less susceptible to leaching of cations (CUCE, 2007) 
Table 3 Exchangeable Bases and Cation Exchange Capacity (CEC) of soil Samples (cmol/kg)

\begin{tabular}{|llllll|}
\hline Farm & $\mathbf{N a}^{+}$ & $\mathbf{K}^{+}$ & $\mathbf{M g}^{\mathbf{2}}$ & $\mathbf{C a}^{\mathbf{2}^{+}}$ & $\mathbf{C E C}$ \\
\hline $\mathrm{A}$ & 0.62 & 0.23 & 0.15 & 3.36 & 4.65 \\
$\mathrm{~B}$ & 1.64 & 0.05 & 0.11 & 2.57 & 4.33 \\
C & 0.86 & 0.45 & 0.15 & 3.36 & 4.85 \\
D & 0.48 & 0.10 & 0.31 & 4.21 & 5.15 \\
E & 1.06 & 0.12 & 0.12 & 2.50 & 3.83 \\
F & 0.48 & 0.08 & 0.22 & 3.56 & 4.37 \\
G & 0.95 & 0.29 & 0.11 & 2.30 & 3.68 \\
\hline
\end{tabular}

\subsection{Heavy Metals}

The concentrations of $\mathrm{Cd}, \mathrm{Cu}, \mathrm{Fe}, \mathrm{Mn}, \mathrm{Ni}$ and $\mathrm{Zn}$ in soil samples are given in figures 1 to 7.The concentrations of the heavy metals in the samples showed that all the studied metals were present in all soil samples except $\mathrm{Cd}$ and $\mathrm{Ni}$. Cd was detected in only two farms (D and G) and the concentration is very insignificant as shown in figure 1.This result is in agreement with the study on heavy metals in soils from central, Nigeria conducted by Sumaila (2014) where Cd was not detected in all farms. It is also similar to results of heavy metals analysis of soils of Bijapur taluka in India where out of the ten farms analysed, Ni and Cd were not detected in two farms (Pujar et al,. 2012). Distribution of heavy metals in soil is continuously altered due to various soil processes and is under the influence of environmental factors. A large share of general cadmium pollution is caused by dumping and incinerating cadmium-polluted waste (Jarup, 2003), these activities may be absent around the farms analysed.

$\mathrm{Cu}$ metal in agricultural soils absorbed by plants becomes especially important in seed production, disease resistance, and regulation of water. Copper is indeed essential, but in high doses it can cause harm (Abbas et al, 2010). The average concentrations of $\mathrm{Cd}, \mathrm{Cu}$ and $\mathrm{Fe}$ metal in soil of all farms was as follows: $\mathrm{Cd}(0.76 \mathrm{mg} / \mathrm{kg}), \mathrm{Cu}(23.60 \mathrm{mg} / \mathrm{kg}), \mathrm{Fe}(2065.90 \mathrm{mg} / \mathrm{kg})$, The FAO/WHO maximum permissible limits (2007) and the EU standards (2002) (Adah et al., 2013) of metals in soil samples from farmlands are ( $\mathrm{Cu}-265, \mathrm{Cd}-3.0, \mathrm{Fe}-1000)$. These heavy metals detected in the soil samples were below the permissible limits but the iron contents of the samples which ranged from 1942.13 to $2205.9 \mathrm{mg} / \mathrm{kg}$ (figure 3) were above the permissible limits of $1000 \mathrm{mg} / \mathrm{kg}$. Fe has been found to occur at high concentrations in Nigerian soil (Adefemi et al., 2007). The high level of Fe could be as a result of the natural basic rock material of the soil (Qian, et al., 1996)

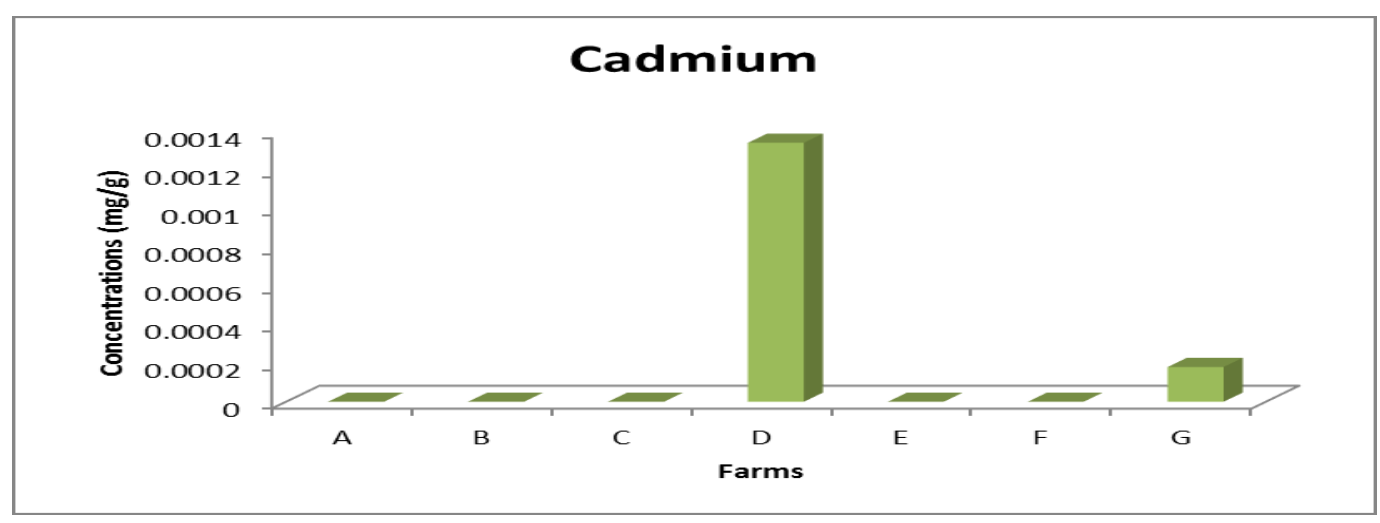

Figure 1: Concentrations in $\mathrm{mg} / \mathrm{g}$ of cadmium metal in soil samples 


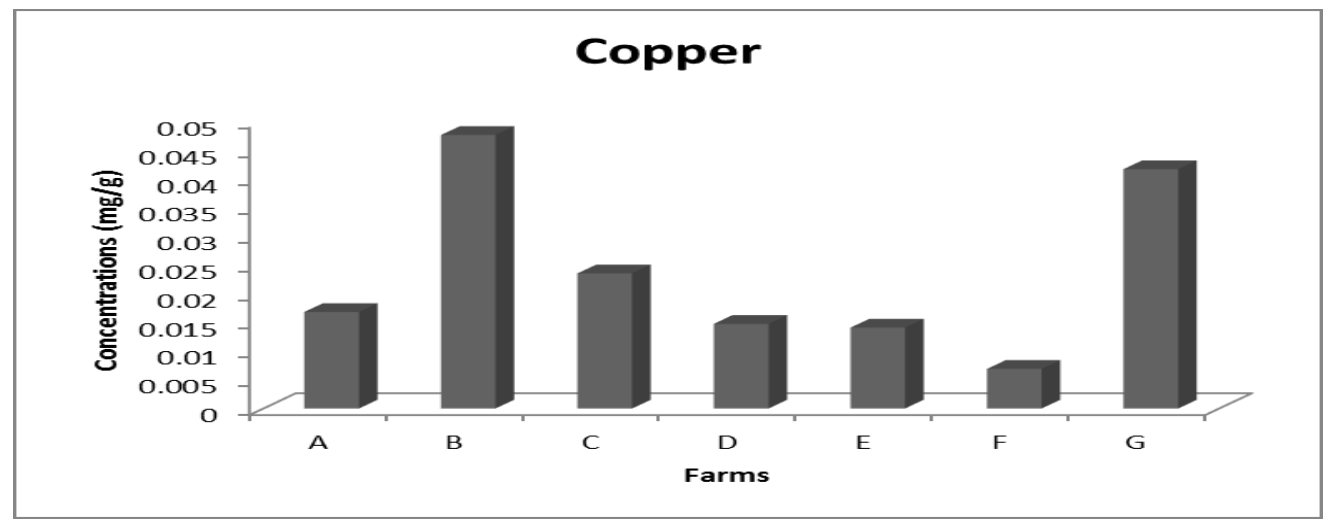

Figure 2: Concentrations in $\mathrm{mg} / \mathrm{g}$ of copper metal in soil samples

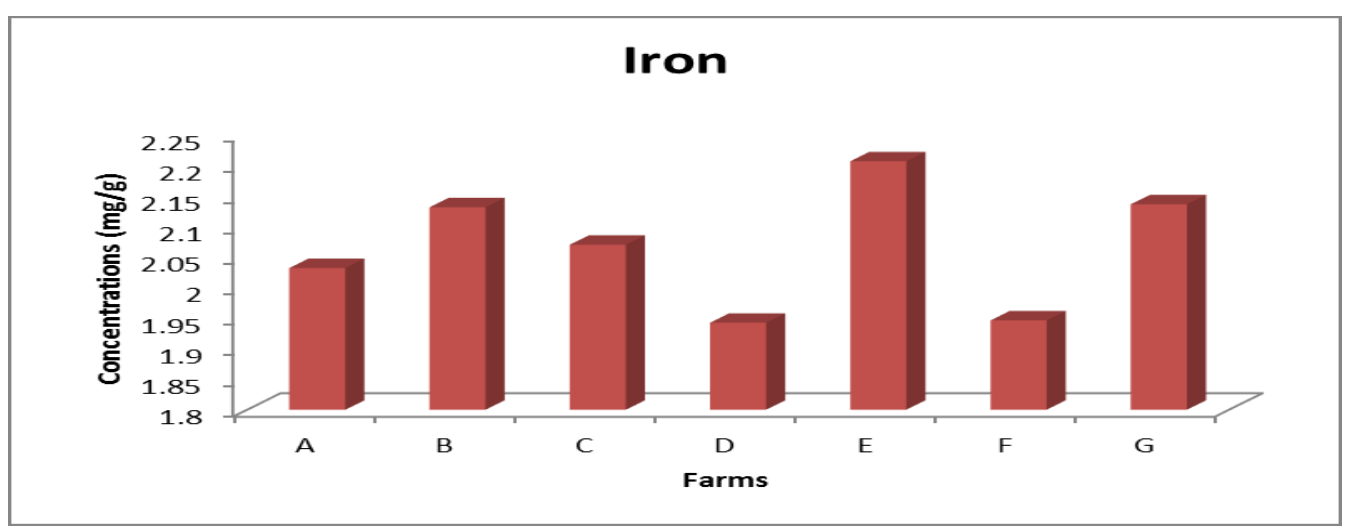

Figure 3: Concentration in $\mathrm{mg} / \mathrm{g}$ of iron metal in soil samples

$\mathrm{Mn}$ is the second most abundant heavy metal after Iron and can find its way into soil from combustion products of motor vehicles, coal burning, pesticides, fertilizers and methylcyclopentadienyl manganese tricarbonyl (MMT) a gasoline additive ((ATSDR, 2000). Nickel is an element that occurs in the environment only at very low levels, its major sources of contamination in the soil are metal plating industries, combustion of fossil fuels, and nickel mining and electroplating (Khodadoust et al., 2004). The result of the study reveals that Ni was absent in farms A, D and F (figure 5), Ni usually take long time for it to be removed from air to other parts of the environment and often leaches down to adjacent groundwater (Wuana and Okieimen, 2011). The average concentrations of $\mathrm{Mn}, \mathrm{Ni}$ and $\mathrm{Zn}$ metal in soil of all farms was as follows: Mn (292.76 $\mathrm{mg} / \mathrm{kg})$, Ni $(3.59 \mathrm{mg} / \mathrm{kg})$ and $\mathrm{Zn}(129.24 \mathrm{mg} / \mathrm{kg})$. The FAO/WHO maximum permissible limits (2007) and the EU standards (2002) of these metals in soil samples from farmlands are Mn-500, Ni75 and $\mathrm{Zn}-600 \mathrm{mg} / \mathrm{kg}$ ).

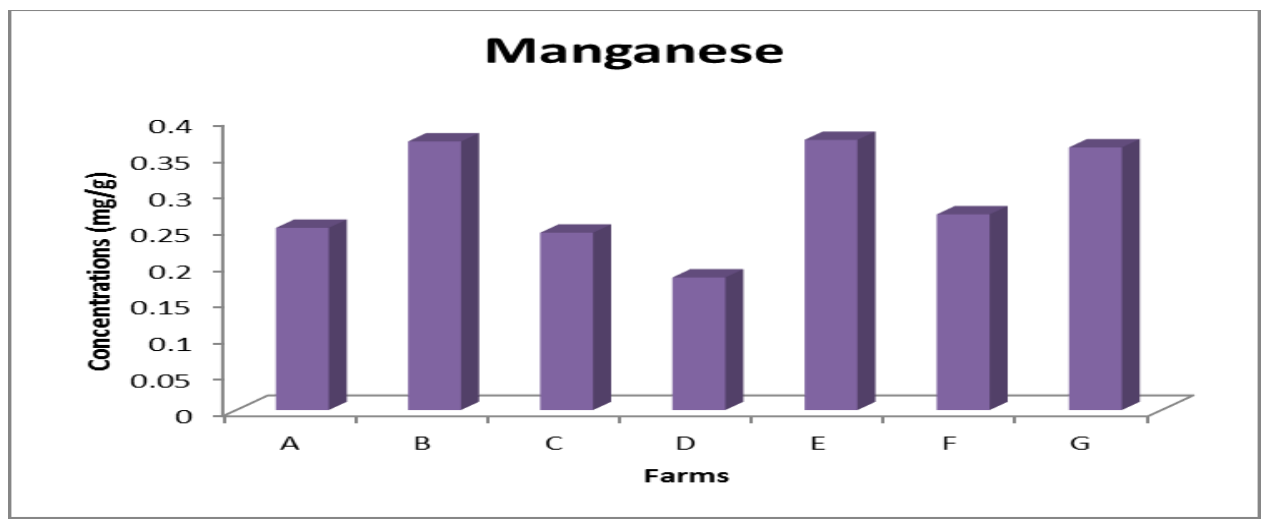

Figure 4: Concentration in $\mathrm{mg} / \mathrm{g}$ of manganese metal in soil samples 


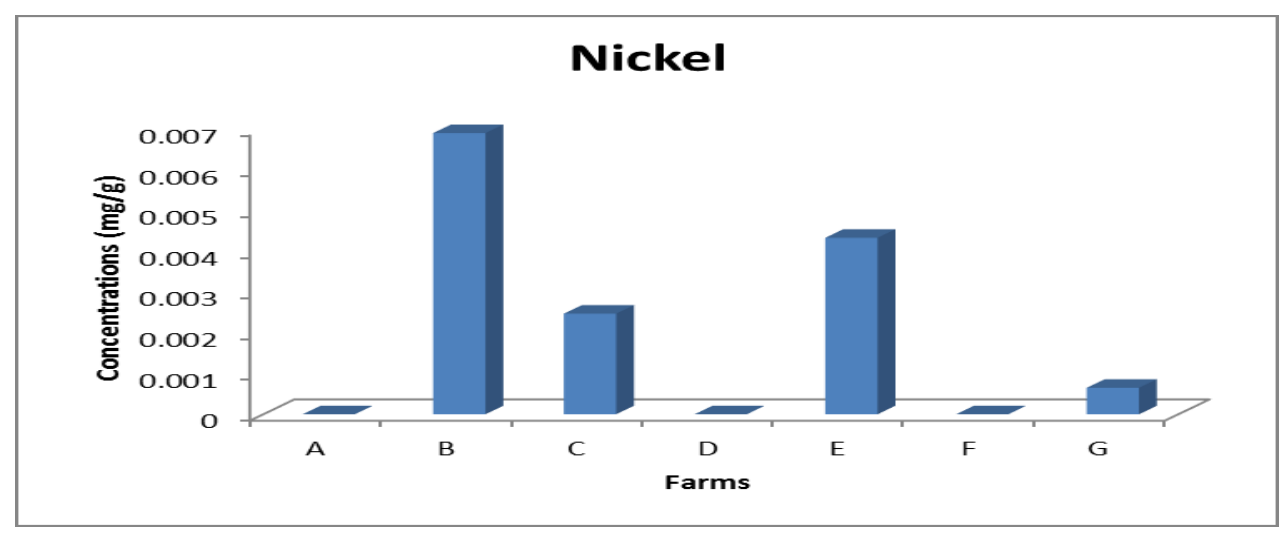

Figure 5: Concentration in $\mathrm{mg} / \mathrm{g}$ of nickel metal in soil samples

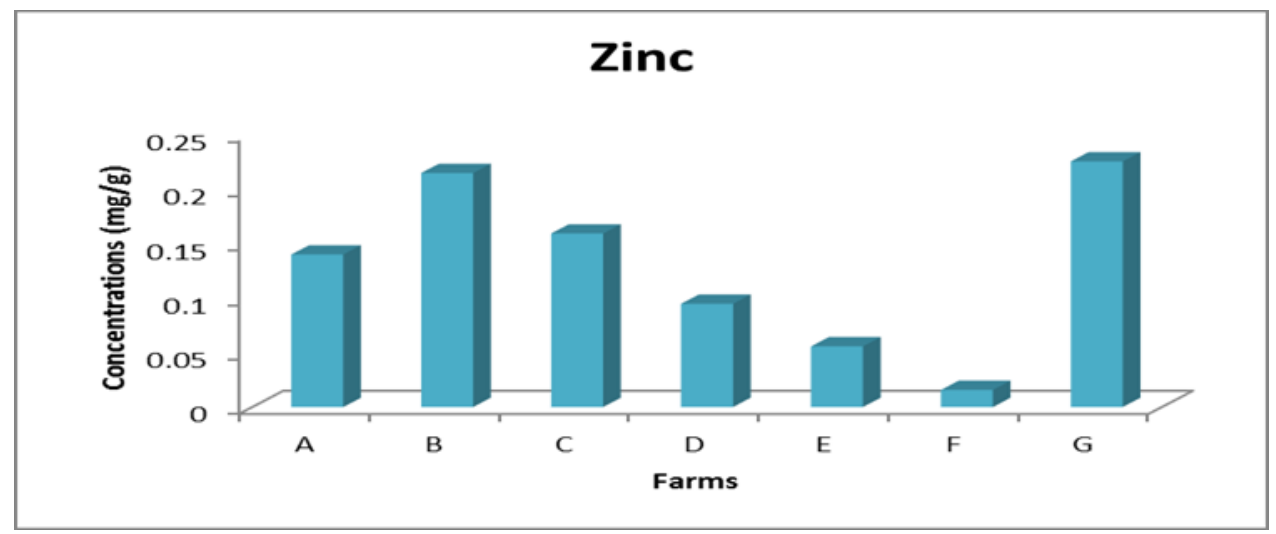

Figure 6: Concentration in $\mathrm{mg} / \mathrm{g}$ of zinc metal in soil samples

Figure 6 shows that $\mathrm{Zn}$ was present in all farms analysed, this may be because it is present in most rocks, weathered out and deposited into the soil. The fate and transport of zinc in the environment is dependent on cation exchange capacity, $\mathrm{pH}$, organic matter content, nature of complexing ligands, and the concentration of the metal in the soil. As $\mathrm{pH}$ increases, there is an increase in negatively charged binding sites on soil particles, which facilitates the adsorption of zinc ions and removal from solution (ATSDR 1994).

The range for $\mathrm{Cu}$ level $(6.71-47.59 \mathrm{mg} / \mathrm{kg})$ obtained was found to be within the range of $5.67-15.17 \mathrm{mg} / \mathrm{kg}$ reported by Sumaila, (2014) for soils around the same area. Iyaka and Kakulu, (2011) also recorded 11.0-26.0 for soil samples from farms around the same geographical region in raining season. This difference could be due to the season this study was conducted (dry season). Concentration of metals in soil vary in dry season and wet season due to the run off effect that is capable of removing high metals from the road side soil and the effect of rain may also facilitate the leaching of the soil and contributes to the dilution of the soil solution (Yahaya et al, 2009, Anhwange, 2009).

In general the concentration of the metals in the soil samples varied according to the following trend $\mathrm{Fe}>\mathrm{Mn}>\mathrm{Zn}>\mathrm{Cu}>\mathrm{Ni}>\mathrm{Cd}$, indicating that all the soil sample had highest level of iron and $\mathrm{Cd}$ was the lowest. The average concentration of all the six metals in each farm also gave the following trend $B>G>E>C>F>D>A$, showing that farm $B$ has the highest average concentration of all the metals combined while farm $\mathrm{A}$ has the least. Physico-chemical analysis results also reveals that Farm A had the highest \% of sand particles and concentration of heavy metal in soil decrease with increase in the sizes of the soil particles (Ajai, et al., 2014)

Farm B is in a densely populated area with motor parks, petrol stations, vehicle repair garages and dumpsites, which suggest possible mobility of metals from the dumpsites to farmlands 
through leaching and runoffs (Opaluwa et al., 2012). Farm $G$ is also close to the main road and aerial deposition could also contribute to metal contents of soils. This is because there is a positive relationship between atmospheric metal deposition and elevated concentrations of heavy metals in top soil (Arora et al., 2008, Debopam et al., 2010).

\section{CONCLUSION}

The physicochemical study of parameters is important for plants growth and soil management. These studies gives information about the acidity or alkalinity of the soil, the soil texture, nutrient content and the soil's ability to hold positively charged ions. Heavy metals were also detected in the soil samples from all farms investigated. The level of $\mathrm{Cd}, \mathrm{Cu}, \mathrm{Mn} \mathrm{Ni}$ and $\mathrm{Zn}$ were below the FAO/WHO and EU standards except for Fe. These heavy metals could be picked up by foodstuffs grown on these farms and pose danger to humans as a result of bioaccumulation. The high level of Fe may constitute health hazards due to its toxicity. Routine physico-chemical and heavy metals analysis of soil samples of agricultural farmlands should be carried out in order to maintain the quality of crops grown on farms.

\section{Reference}

[1] Abbas M, Parveen Z, Riazuddin Iqbal S, Bhutto R (2010) Monitoring of toxic metals (cadmium, lead, arsenic, and mercury) in vegetables of sindh, Pakistan, Kathmandu university. Journal of Science, Engineering and Technology 6, 60-65

[2] Adefemi OS, Olaofe D, Asaolu SS (2007) Seasonal variation in heavy metal distribution in the sediment of major dams in Ekiti-State. Pakistan Journal of Nutrition 6(6): 705-707

[3] Adriano DC (1986) Trace elements in the terrestrial environment, New York, Springer Verlag, 107-469.

[4] Agency for Toxic Substances and Disease Registry, ATSDR (1994) Toxicological Profile for Zinc. US Department of Health and Human Services, Public Health Service 205-88-0608.

[5] Agency for Toxic Substances and Disease Registry, ATSDR (2000) Toxicological profile for manganese. U.S. Centers for Disease Control. http://www.atsdr.cdc.gov/toxprofiles/tp151.html.

[6] Ajai, A.I., Iyaka, I. A., Ndamitso, m. and Uwem, B. (2014). Determination of physicochemical and heavy metal content of soil around paint industries in Kaduna. International Journal of Scientific \& Technology Research, 3(8), 221-225.

[7] Allen SE (ed.) (1974). Chemical analysis of ecological materials. Blackwell, London.

[8] Anhwange BA, Kagbu JA, Agbaji EB, Gimba CE (2009) Trace metal contents of some common vegetables grown on irrigated farms along the banks of river Benue within Makurdi Metropolis. Electronic Journal of Environment and Agricultural Food Chemistry 8, 11501155.

[9] Arora M, Kiran B, Rani S, Rani A, Kaur B, Mittal N (2008) Heavy metal accumulation in vegetables irrigated with water from different sources. Food Chemistry 111, 811-815.

[10] Bashir, F., Tariq, M., Khan, M.H., Khan,R.A... Aslam, S. (2014) Fractionation of Heavy Metals and Their Uptake by Vegetables Growing in Soils Irrigated with Sewage Effluent. Turkish Journal of Engineering \& Environmental Sciences. 38, 1 - 10.

[11] Boulding JR (1994) Description and sampling of contaminated soils. Afield Guide. 2nd Edn. Lewis Publishers, Boca Raton, FL 
[12] Cornell University Cooperative Extension (CUCE) (2007) Cation Exchange Capacity (CEC). Agronomy Fact Sheet Series \# 22. Department of Crop and Soil Sciences, College of Agriculture and Life Sciences, Cornell University.

[13] Debopam B, Himadri B, Sibabrata M, Anju P, Debabrata B, Lalitagauri R (2010) Heavy metal contamination in fruits and vegetables in two districts of West Bengal, India. Electronic Journal of Environment \& Agricultural Food Chemistry 9, 1423-1432.

[14] Dosumu OO, Abdus-Salam N, Oguntoye S, Adekola FA (2005) Trace metals bioaccumulation by some Nigerian vegetables. Centrepoint (Science Edition), 13(1): 23-32

[15] GWRTAC, (1997) Remediation of metals-contaminated soils and groundwater, Tech. Rep. TE-97-01. Pittsburgh, Pa, USA, GWRTAC-E Series.

[16] Hazelton PA, Murphy BW (2007) Interpreting soil test results: What do all the numbers mean? CSIRO Publishing, Melbourne.

[17] Horwath WR (2005) The importance of soil organic matter in the fertility of organic production systems, Western Nutrient Management Conference, Salt Lake City, UT. 6: 244249.

[18] Iyaka YA, Kakulu SE (2009) Copper and zinc contents in urban agricultural soils of Niger State, Nigeria. African Research Review, an International Multi-disciplinary Journal, Ethiopia (3), $23-33$.

[19] Jain TB, Graham RT, Adams DL (1997) Carbon to organic matter ratios for soils in Rocky Mountain coniferous forests. Soil Science Society of America Journal 61: 1190-1195.

[20] Khan S, Cao Q, Zheng YM, Huang YZ, Zhu YG (2008) Health risks of heavy metals in contaminated soils and food crops irrigated with wastewater in Beijing, China, Environmental Pollution 152(3): 686-692.

[21] Khodadoust AP, Reddy KR, Maturi K (2004) Removal of nickel and phenanthrene from kaolin soil using different extractants, Environmental Engineering Science 21(6): 691-704.

[22] Kiran GC (2013) Studies of physico-chemical parameters of different soil samples. Archives of Applied Science Research 6, 72-73.

[23] McLaughlin MJ, Parker DR, Clarke JM (1999) Metals and micronutrients - Food safety issues, Field Crops Resources 60: 143-163.

[24] Moore G, Dolling P, Porter B, Leonard L (1998) Soil acidity. In Soil guide. A handbook for understanding and managing agricultural soils (Ed. G Moore) Agriculture Western Australia Bulletin No. 4343.

[25] Olukanmi DO, Adeoye DO (2012) Heavy metal concentrations in road side soils from selected locations in the Lagos Metropolis, Nigeria. International Journal of Engineering and Technology 2(10)

[26] Omojola MO (1993) Modification of urea with maize cob waste for use as slow release nitrogen fertilizer. Dissertation, Ahmadu Bello University Nigeria pp 111-116.

[27] Opaluwa OD, Aremu MO, Ogbo LO, Abiola KA, Odiba IE, Abubakar MM, Nweze NO (2012) Heavy metal concentrations in soils, plant leaves and crops grown around dump sites in Lafia Metropolis, Nasarawa State, Nigeria. Advances in Applied Science Research 3(2): 780-784.

[28] Périé C, Ouimet R (2008) Organic carbon, organic matter and bulk density relationships in boreal forest soils. Canadian Journal of Soil Science 88: 315-325. 
[29] Popoola OE, Bamgbose O, Okonkwo OJ, Arowolo TA, Odukoya O, Popoola AO (2012) Heavy metals content in playground topsoil of some public primary schools in metropolitan Lagos, Nigeria. Research Journal of Environmental and Earth Sciences 4(4): 434-439.

[30] Pujar KG, Hiremath SC, Pujar AS, Pujeri US, Yadawe MS (2012) Analysis of physicochemical and heavy metal concentration in soil of Bijapur Taluka, Karnataka. Science Revisions and Chemical Communication 2(1): 76-79.

[31] Singh B (2001) Heavy metals in soils: Sources, chemical reactions and forms. In: Smith D, Fityus S, Allman M (ed.): Proceedings of the 2nd Australia and New Zealand.

[32] Sumaila A (2014) Assessment of some heavy metals in selected vegetables and soils obtained from farm sites in Paiko, Niger State, Nigeria. Dissertations, Federal University of Technology Minna, Nigeria

[33] Troeh FR, Louis MT (2005) Soils and soil fertility. 6th ed. Ames, Blackwell, Iowa.

[34] Wuana RA, Okieimen, FE (2011) Heavy metals in contaminated soils: A review of sources, chemistry, risks and best available strategies for remediation. Retrieved from http://dx.doi.org/10.5402/2011/402647

[35] Yahaya MI, Ezeh GC, Musa YF, Mohammad SY (2009) Analysis of heavy metals concentration in road side soils in Yauri, Nigeria. African Journal of Pure and Applied Chemistry 4(3): 22-30.

[36] Yusuf KA, Oluwole SO (2009) Heavy metal $(\mathrm{Cu}, \mathrm{Zn}, \mathrm{Pb})$ contamination of vegetables in urban city: A case study in Lagos. Research Journal of Environmental Science 30, 292-298.

[37] Zhang MK, Liu ZY, Wang H (2010) Use of single extraction methods to predict bioavailability of heavy metals in polluted soils to rice. Communication in Soil Science and Plant Analysis 41(7): 820-831. 